\title{
Opmerkings oor die teologie van Psalm 106
}

\author{
JP Oberholzer
}

\section{Abstract}

Remarks on the theology of Psalm 106

A structural analysis of this liturgical song shows up the prayer for deliverance (vs 47) as focal point, cast against the background of the confession of guilt (vs 6), elaborated by reference to past history. Theologically the psalm is representative of what can be found on many pages of the Old Testament. A liturgy constructed around the history between God and man finds full richness in the contrast between divine and human acts and in the confession of the saving grace which gives life in spite of the contrast.

Die opskrif van hierdie artikel, wat ek met erkentlikheid aan 'n groot geleerde, 'n toegewyde gelowige en 'n kinderlike prediker wy, het rede. Die teologie van Psalm 106, dit wil sê die psalm se getuienis oor God en sy handelinge, omvat 'n groot deel van wat beskryf sou kon word as die teologie van die Ou Testament. Dit bly daarom by opmerkings, sonder selfs die pretensie om meer te gedoen het as an die oppervlakte te gekrap het en verblind te wees deur die rykdomme wat daar wag om ontginning.

Die verwysing na die geskiedenis wat so 'n groot deel van Psalm 106 uitmaak, speel ook elders 'n belangrike rol. Dit geskied hoofsaaklik in twee vorme: Daar is ' $n$ aantal tekste waarin na die geskiedenis verwys word met al die klem op die dade van die Here. Hieronder val Deuteronomium 6: 21-23, 'n kategetiese parenese; Deuteronomium 26: $5-9$, 'n formulier by die offer van die eerste opbrengs van die oes; Josua 24: $2-13,17-18$, 'n formulier by verbondsluiting; Psalm 105, 'n verbondsparenese met die Abrahamsverbond as uitgangspunt; Psalm 135: $8-12$, 'n loflied met die verkiesing van Israel as tema; Psalm 136, 'n loflied met die gawe van die land as tema.

'n Tweede vorm waarin na die geskiedenis verwys word, kom voor in dié tekste waar die klem spesifiek lê op die teenstelling tussen die dade van die Here en die optrede van sy volk. Hieronder val Psalm 78, 'n kategetiese parenese met die verkiesing van Sion en Dawid as tema; 
Nehemia 9: 6-31, 'n loflied met skuldbelydenis gevolg deur 'n belofte; en Psalm 106, 'n loflied met skuldbelydenis en ' $n$ gebed om bevryding uit die ballingskap. By hierdie laaste reeks kan ons ook voeg Handelinge 7: 2-55, die aanklag teen die Joodse Raad soos uitgespreek deur Stefanus. Dit is duidelik dat in elkeen van hierdie tekste die verwysing na die geskiedenis nie ' $n$ doel in sigself is nie, maar in diens staan van ' $n$ bepaalde struktuur. In die meeste gevalle dien dit ter illustrasie van ' $n$ bepaalde situasie in die verhouding tussen die sprekers en Jahwe.

Dit is ook die geval met Psalm 106, soos duidelik blyk wanneer ons sy strukturele elemente ontleed. Die lofprysing waarmee hierdie lied begin en eindig sowel as die parenetiese spreuk in vers 3 vorm ' $n$ omraming wat hierdie lied liturgies bruikbaar gemaak het ook vir later tye. Die eintlike liggaam van die lied word gevorm deur verse 4-47, naamlik die gebed van 'n enkeling om gemeenskap met die uitverkorenes, vers 4 en 5 ; ' $n$ kollektiewe skuldbelydenis, vers 6 , geïllustreer deur die verwysing na die geskiedenis vers 7-46; en 'n gebed om redding vers 47 . Dit is duidelik dat die swaartepunt van die lied juis in vers 47 lê. Die gebed om gemeenskap met die uitverkorenes, die skuldbelydenis en die verwysing na die geskiedenis vorm tesame die aanloop op die gebed om redding.

In die vertaling wat volg, word die onderskeie elemente aangedui. Ter wille van die aanduiding van bepaalde styl- en inhoudskenmerke word ' $n$ redelik konkordante weergawe gemaak. Die probleem van meersinnigheid is as probleem gelaat ten einde iets te probeer weergee van die klem wat in die psalm val op die interaksie tussen die twee hoofakteurs. Aan die een kant word die Godsname spaarsamig gebruik (Jahwe: 2, 4, 16, 25, 40; El: 14, 21; Jahwe ons God: 47, Jahwe God van Israel 48), aan die ander kant word Israel telkens deur middel van die persoonlike voornaamwoord as 't ware vasgemaak aan Jahwe (u volk 4, sy volk 40 , u uitverkorenes 5 , u nasie 5 , u eie volk 5 , sy eie volk 40 ). Die groot spel is egter dié van die voornaamwoorde: ' $n$ ' $E k^{\prime}$ wat bid om solidariteit met die volk van Jahwe, 'n 'ons' wat skuld bely en om redding bid, 'n 'hulle' wat 'ons voorvaders' is en die sondegeskiedenis gemaak het, teenoor die ' $U$ ' van nou, die 'Hy' van die geskiedenis.

\section{PSALM 106}

\section{Doksologie}

1. Halleluja!

Loof Jahwe, want Hy is goed, ja, vir altyd sy liefde! 
2. Wie kan die magsdade van Jahwe in woorde omsit, sy lof ten volle laat hoor?

\section{Parenetiese spreuk}

3. Voorspoed vir dié wat die reg in stand hou, dié wat reg doen deurentyd!

\section{Gebed om deel in die gemeenskap}

4. Dink aan my, Jahwe, in u geneentheid teenoor $u$ volk, hou my in gedagte in $u$ reddende werk,

5. sodat ek die voorspoed van u uitverkorenes kan beleef, bly kan wees in die blydskap van u nasie, my kan verheug saam met $u$ eie volk.

\section{Skuldbelydenis}

6. Ons het gesondig saam met ons voorvaders, Ons het verkeerd gedoen, ons is skuldig!

\section{Verwysing na die geskiedenis}

7. Ons voorvaders in Egipte het nie ag geslaan op $u$ wonderdade nie, hulle het nie gedink aan die oorvloed van u liefdesdade nie en hulle was in verset by die see, by die Rietsee.

8. Tog het Hy hulle gered ter wille van sy Naam, om sy mag bekend te maak.

9. Hy het die Rietsee aangespreek en dit het opgedroog:

Hy het hulle laat deurgaan deur die watervloede heen asof dit woestyn was.

10. So het Hy hulle gered uit die mag van die hater, hulle verlos uit die mag van die vyand.

11. Die waters het hulle teenstanders toegemaak; nie een van hulle het oorgebly nie.

12. Daarom het hulle geglo in sy woorde, het hulle sy lof besing.

13. Maar hulle het gou vergeet wat Hy gedoen het, en hulle nie gehou aan sy raad nie. 
14. Hulle het hulle vraatsug laat botvier in die woestyn, hulle het El beproef in die wilde wêreld.

15. Toe het Hy hulle gegee wat hulle gevra het, maar ook ' $n$ uitterende kwaal onder hulle in gestuur.

16. Hulle was vol naywer teen Moses in die laer, teen Aäron, gewyde van Jahwe.

17. Die aarde het oopgeskeur en vir Datan opgesluk, dit het toegemaak oor die bende van Abiram.

18. ' $n$ Vuur het hulle bende verteer, die vlamme het die skuldiges verbrand.

19. Hulle het 'n kalf gemaak by Horeb, hulle het gebuig voor 'n stuk gietwerk,

20. hulle het hulle Magtig-Teenwoordige verruil vir 'n bees wat gras vreet,

21. hulle het hulle Redder $\mathrm{El}$ vergeet, Hy wat groot dinge in Egipte gedoen het,

22. wonderdade in die land van Gam, ontsagwekkende dinge by die Rietsee.

23. Hy het gepraat om hulle uit te wis, maar sy uitverkorene, Moses, het in die bres gaan staan vir hulle om sy gramskap af te keer, sodat hulle nie verdelg sou word nie.

24. Hulle het die kosbare land versmaai, hulle het nie geglo in sy woorde nie,

25. hulle het in hulle tente gesit en mor, hulle het nie geluister na die stem van Jahwe nie.

26. Toe het Hy 'n eed geneem teen hulle om hulle te laat omkom in die woestyn,

27. om hulle nageslag te laat omkom onder die nasies en hulle te verstrooi oor die lande.

28. Hulle het Baäl-Peor gedien en die offermaaltye vir dooie gode geëet.

29. So het hulle Hom getart met hulle optrede, en 'n plaag het uitgebreek onder hulle.

30. Pingas het tevoorskyn getree en gestraf, en die plaag het opgehou.

31. Dit is vir hom as ' $n$ goeie daad gereken van geslag tot geslag, vir altyd. 
32. Hulle het sy toorn laat ontvlam by Meribawater, en Moses het ter wille van hulle in die moeilikheid gekom.

33. Hulle het sy gemoed verbitter, sodat hy onbesonne dinge gesê het.

34. Hulle het nie die volke uitgeroei wat Jahwe vir hulle gesê het nie,

35. hulle het ondertrou met die nasies, dié se optrede aangeleer

36. en hulle afgode gedien, sodat dit vir hulle die valstrik geword het.

37. Hulle het hulle seuns geoffer, en hulle dogters, aan die veldduiwels.

38. Ja, hulle het onskuldige bloed vergiet, die bloed van hulle eie seuns en dogters wat hulle aan die afgode van Kanaän geoffer het.

So is die land met moord besoedel.

39. Dit is verontreinig deur hulle dade; hulle het troubreuk gepleeg met hulle optrede.

40. Daarom het die toorn van Jahwe ontbrand teen sy volk en het Hy Hom gewalg aan sy eie volk.

41. Hy het hulle oorgegee in die mag van die nasies; hulle haters het die mag oor hulle gekry.

42. Hulle vyande het hulle verdruk en hulle laat buig onder hulle mag.

43. Keer op keer het Hy hulle bevry maar hulle het hulle eiesinnig bly verset en dieper weggesink in hulle verkeerdheid.

44. Tog, Hy het hulle raakgesien in hulle nood, Hy het hulle smeekbede gehoor.

45. Hy het sy verbond met hulle in gedagte gehou, Hy het Hom ontferm in sy groot liefde

46. en hulle erbarming laat vind by almal wat hulle gevange gehou het.

\section{Gebed om redding}

47. Red ons, Jahwe ons God, maak ons bymekaar onder die nasies uit, 
sodat ons $u$ heilige Naam kan roem

en ons kan verheug in $u$ lof.

\section{Lofprysing}

48 Lof aan Jahwe, God van Israel, van die ver verlede af tot die verre toekoms toe!

Die hele volk moet sê: Amen!

Halleluja!

Daar is verskillende opmerklike sake wat hulle by die lees van die psalm aan ' $n$ mens se aandag opdring. So byvoorbeeld val die terminologiese opstapeling op: 'n wye verskeidenheid terme word gebruik vir die dade van Jahwe, (magsdade, reddende werk, wonderdade, liefdesdade, groot dinge, ontsagwekkende dinge) en veral vir die sonde van Israel (minstens sestien algemene terme naas spesifieke beskrywing). Tesame genome kan hierdie terminologie op sigself al aanduiding daarvan wees dat dié psalm 'n lang teologiese ontwikkelingsgang weerspieël. Ons het hier te doen met teologiese begrippe wat reeds vaste inhoud het en elk op eie wyse 'n belydenis en verkondiging bevat.

'n Tweede saak wat opval in die verwysing na die geskiedenis, is dat daar ' $n$ progressie van sonde is. Die verwysing begin met ' $n$ bepaalde ritme, naamlik sonde, redding en geloof (vers 7-12), en vorder tot 'n situasie waarin sonde op sonde volg met toorn en straf as resultaat, vers 32-42. Na die Rietsee het geloof gevolg, na Kades ongeloof (vgl vers 12 en 24). Juis dié Moses wat vir hulle in die bres getree het by Sinai is dié een met wie dit sleg gaan by die Meribawaters deur hulle toedoen (vgl vers 23 en vers 32 ).

'n Derde opmerklikheid in die verwysing na die geskiedenis is dat ons te doen het met interpretasie van historiese gebeure eerder as met geskiedenisvertelling. Dit lei tot 'n geskiedenisstruktuur wat die kontras beklemtoon tussen die liefde, redding en bevryding van die kant van Jahwe enersyds, en die sonde, verset en uittarting van die kant van Israel andersyds. Die geskiedenis kom so te voorskyn as ' $n$ beweging waarin die groot reddingsdade in hulle skeppende werking weerstaan word deur die toorn en straf in sy vernietigende werking, 'n beleefde werklikheid op die rand van die afgrond.

'n Vierde opmerklike saak is dat toorn en straf steeds as reaksie van 
die kant van Jahwe teenoor die optrede van die volk beskryf word, terwyl redding en genade as 'n wesenshandeling van Jahwe te voorskyn kom. Die liefde en geneentheid van Jahwe het geen grond anders as sy verbond nie, terwyl sy toorn en straf te voorskyn geroep word deur die dade van sy volk. Lewe en behoud vir dié volk berus op die groot ten-spyte-van.

Op sigself genome vertoon Psalm 106 'n teologiese rykdom wat in sigself ' $n$ verteenwoordigende samevatting vorm van baie wat in die res van die $\mathrm{Ou}$ Testament te vind is. Om te begin by die bede om redding, vers 47 , wat ons vroeër aangedui het as die kern van hierdie psalm; hierdie gebed berus op geloof, dié geloof naamlik dat Jahwe soewerein genadig was en is en sal wees; anders gesê, dat sy genade, wat 'n wesenshandeling van Hom is, dit moontlik maak dat Hy die volk uit sy huidige nood sal red. Dit berus daarop dat Hy in die verlede gered het en dat dit steeds ' $n$ redding was ten spyte van wat Israel gedoen het. Toorn en straf wás daar in die geskiedenis omdat Israel dit te voorskyn geroep het, maar dit was steeds reaksie en nie wesenstrek van Jahwe, die God van Israel, nie. Die gebed om redding kom dan ook voort uit die oortuiging dat selfs die weersin van Jahwe in sy volk oorwin sal word deur sy liefde, maar dit was genade ten spyte van hulle (43-46).

Die gebed om redding volg na skuldbelydenis, en wel 'n skuldbelydenis wat uitgespreek word in solidariteit met die volk van die geskiedenis. Daardeur vind vereenselwiging plaas met die totale skuld in die hele geskiedenis tussen God en sy volk. Opmerklik is die rol wat vers 4 en 5 in hierdie samehang speel. Dit lyk korrek om saam met die masoretiese lesing die eerste persoon enkelvoud te behou, sodat die individu hierdeur eers die bede uitspreek om ingesluit te word in die liefde van Jahwe vir sy volk en te mag deel in die voorreg en vreugde van daardie volk, om dan direk hom te vereenselwig met die sonde van die vadere en sy skuldbelydenis uit te spreek in gemeenskap met die volk van nou én van die verlede.

Die visie op die sondegeskiedenis van die verlede verhinder nie dat die Godsvolk aangedui word met 'n reeks benaminge wat die volk onlosmaaklik verbind aan Jahwe nie. Wat hierdie volk is, is hy omdat Jahwe hom dit gemaak het, maar sy dade staan in skrille kontras daarmee. Dié visie op die geskiedenis lei dan ook vanself tot die lof van Jahwe en tot skuldbelydenis oor die eie aandeel in die geskiedenis. Die individu wat deel in die liturgie, vind sy identiteit in sy gemeenskap met die Godsvolk, en die Godsvolk op sy beurt vind sy identiteit in sy gebed om redding, 'n gebed wat voortkom uit die belydenis van die 
dade van God in teenstelling met die dade van die volk soos dit in die geskiedenis vertoon word.

Belydenis en gebed op dié wyse kan net geskied deur diegene wat die toorn en straf van God as ' $n$ totale bedreiging ervaar het. In die woorde van Psalm 90: 11, '. . wie ken die krag van u toorn beter as u dienaars'. Hier is mense aan die woord wat oor ' $n$ lang tydperk op verskillende wyses die nabyheid van God geken het, 'n nabyheid in redding, maar ook' $n$ nabyheid in toorn en straf. ' $n$ Liturgie wat gevorm word rondom die geskiedenis tussen God en mens, kry dan sy volle rykdom in die kontras tussen die goddelike en die menslike handeling en in die belydenis van die genade wat die lewe moontlik maak ten spyte van daardie kontras. Die doksologie waarmee hierdie psalm begin en eindig, betuig op eie wyse die kontras met wat in die verwysing na die geskiedenis gestel word en ook met die huidige toestand van die volk soos dit tot uiting kom in die agtergrond van die bede om redding.

Wat sy teologiese struktuur betref, is Psalm 106, soos bo gestel, verteenwoordigend en samevattend van wat op talle bladsye van die Ou Testament gevind word, en strek dit inderdaad by die grense van die Ou Testament verby. Die twee trekke, redding-deur-die-straf-heen en genade-ten-spyte-van, is albei ook teenwoordig in die teologiese struktuur wat ons in die Nuwe Testament aantref rondom die versoenende sterwe en opstanding van Christus. Wat dit betref, staan Psalm 106 dus in die hoofstroom van die Christelike teologie en het hy tot vandag toe ' $n$ besondere appèl binne die teologie van ons tyd. Sowel die volk se selfverheffende teologie wat hom oriënteer aan die DawidSions-ideologie as die bevrydingsteologie wat hom oriënteer aan 'n vertekende beeld van die eksodus-ideologie in die Ou Testament, loop hulle te pletter teen die teologie van die geskiedenis soos dit in hierdie psalm weerspieël word. Die soewerein genadige God wat in hierdie psalm geloof en gesmeek word, bly Homself, en wat die mens voor Hom kan sê, is uiteindelik niks meer as die gebed om redding en die lof aan Hom wat goed is en aan wie se liefde daar geen einde is nie. 